\title{
Zika Virus Antibody Measurement
}

National Cancer Institute

\section{Source}

National Cancer Institute. Zika Virus Antibody Measurement. NCI Thesaurus. Code C147451.

The determination of the amount of Zika virus antibody present in a sample. 